
\title{
28 Research Square \\ Pulp and Papermaking Characteristics of South Sudanese Cordia Africana (Gambil) Wood
}

\section{Osman Taha Elzaki}

Institute of Technological Research, National Centre for Research

\section{Selim Otuk Tuphach}

University of Upper Nile, Malakal, South Sudan

\section{Tarig Khider ( $\nabla$ tarigosmankhider@gmail.com )}

University of Bahri, College of Applied and Industrial Sciences https://orcid.org/0000-0003-4494-8402

\section{Research Article}

Keywords: Cordia africana, physical properties, Fibre dimensions, Chemical composition, Pulping conditions, Papermaking.

Posted Date: May 9th, 2020

DOI: https://doi.org/10.21203/rs.3.rs-27401/v1

License: @ (i) This work is licensed under a Creative Commons Attribution 4.0 International License. Read Full License 


\section{Abstract}

The wood of an important indigenous Sudanese hardwood species, Cordia africana lam, was examined to determine its suitability for pulp and papermaking. Basic density, bark-to-wood ratio, fiber dimensions and chemical composition were studied. Pulps were evaluated and papermaking characteristics were tested.

C. africana wood showed medium basic density $\left(410 \mathrm{~kg} \mathrm{~m}^{-1}\right)$. The average bark-to wood ratio by mass $(6.82 \%)$ and volume $(11.67 \%)$ were in the normal average for pulpwood and could be used for production of high grade pulp.

The fibers of $C$. africana were long with an average fiber length of $1.13 \mathrm{~mm}$, average fiber diameter was $30 \mu \mathrm{m}$ with an average lumen diameter $20 \mu \mathrm{m}$ and cell wall thickness of $5 \mu \mathrm{m}$. the wood showed high ash content $(2.7 \%)$, high pentosans $(25 \%)$, relatively medium lignin content $(23.9 \%)$.

C. africana pulped with $12-15 \%$ alkali charge as $\mathrm{Na}_{2} \mathrm{O}$ for two hours at $170{ }^{\circ} \mathrm{C}$ gave good Kappa numbers with normal and relatively high yield with very low rejects. The addition of $0.13 \%$ anthraquinone (AQ) in cooking liquor reduced the active alkali consumption by $2-2.3 \%$, increased the pulp yield and reduced bleachable Kappa numbers. The pulp produced suitable for wrapping paper and paperboard.

\section{Introduction}

The species Cordia africana Lam,family Boraginaceae, sub family Cordiodeae synonym: C. holstii., Cordia abyssinica R.Br (Friis,1992). Its common names in different languages are East African cordia, large-leafed cordia, Sudan teak (English) Gambil (Arabic) Makobokobo (Swahili). Makumari, Muringa (Kikuyu), Samotet (Nan). It is small to medium-size tree occurs at medium altitudes, savannah and bush, near river banks. Its size between 6-9 meters, sometimes $16.6 \mathrm{~m}$ high (Sahni, 1668, Bolza, 1972, Palgrave, 1988, El Amin, 1990, Orwa et al.2009, Raga and Denu, 2017). Cordia composed of five species distributed in different areas of the Sudan (Andrews, 1956), although there are great differences in morphological structure of the species (Guyassa, et al, 2013), there are no anatomical differences of these species (Ahmed and Kordofani, 2012). C. africana is the fast growing and has high economical value due to its timber uses (Tamene, 2017).

The wood of Cordia africana is utilized for timber production, farm equipment, household utensils and fuel (Emmanuel Neba, 2010; FAO, 2007; ICRAF, 2008; Jansen 1981; Loha et al,2009; Obeng, 2010; Royal Botanic Gardens, 2009; Takaoka, 2008), and also used in construction and manufacturing of toys ((Obeng, 2010). Amhara tribes in Ethiopia use this tree in rituals of orthodox religion (Baye, 2016). The wet parts of $C$. africana bark is applied to heal the broken bones (Schmidt and Mwaura, 2010).

Although Sudan was politically divided into two countries in 2011, the social scientific relations still continuing, the border between the two countries open with more or less similar environmental, ecological conditions and plant tree composition (Issa et al, 2018 and Elzaki, et al 2012). 
South Sudan is largely dependent on the imports of paper products. The demand for these products have grown rapidly with continuous development. Pulp can be produced in many different yields depending on the suitability of the raw material and pulping conditions.

Wood as raw material for pulp and papermaking has offered precious services to man and decisively contributed to development and civilization (Khristova et al, 1989). Sudan and South Sudan is rich in different hardwood species many of which could be a good source of pulp production (Elzaki, 1990). The study of such wood species is important to determine their suitability for pulp production. Among the important indigenous Sudanese hardwood species is Cordia Africana. The species is naturally distributed in western Darfur (Jebel Marra), Blue Nile and southern Kordofan, and in South Sudan (Equatoria, Upper Nile and Bahr el Ghazal).

This study aimed to investigate the pulping and paper properties of $C$. Africana stem with reference to fiber dimensions and chemical composition.

\section{Materials And Methods}

Five $C$. Africana trees with average age six years, were randomly selected according to TAPPI standards 2002 from Jelhag natural forest (Upper Nile state, South Sudan). The trees were felled and branches were removed, transported to Khartoum capital of Sudan by bus, stored in National Centre for Research NCR). Leaves, flowers fruits and seeds were collected for identification with taxonomists of Medicinal and Aromatic Plants Research Institute National Center for Research, Sudan (Issa et al, 2018).

Five logs of $100 \mathrm{~cm}$ long were exposed to air dry under sun, prepared according to TAPPI standard (T 257-cm- 02), chipped with hands and packed in plastic bags for further analysis. The average basic density was determined using wood specimens according to the British standards (B.S., 1957). Wood fibers were macerated using a mixture of $30 \%$ hydrogen peroxide and acetic acid (1:1). Fiber dimensions were determined microscopically at X100 and X 300 magnifications according to (TAPPI-232cm-01) after staining with aqueous safranin (Horn 1978). Standard deviation and arithmetical mean were used to determine fiber properties Morphological indices. The heat value of $C$. Africana wood was carried out using a Krocher oxygen bomb calorimeter (Khider and Elzaki, 2012).

About one Kg of chips was grinded for chemical Analysis of wood sample was carried out using 40 to 60 mesh wood meal in accordance with (TAPPI-264-cm-97). Sampling and testing for moisture (TAPPI210cm-93), cellulose Kurshner and Hoffer (Obolenskaya et al, 1965), lignin (TAPPI-222), Pentosans (TAPPI-223-cm-01), ash (TAPPI-212) hot water soluble (TAPPI-T- 207) and solvent extraction of wood (TAPPI-204).

After negotiations and suggestions with other coauthors the pulping conditions and cooking parameters were decided according to physical properties Cordia africana wood and mainly on its chemical components. The Soda and soda-anthraquinone conditions were $12-15 \% \mathrm{as}^{\mathrm{Na}} \mathrm{O}_{2} \mathrm{O}$ on oven dry weight of wood, the maximum temperature was kept constant at $170^{\circ} \mathrm{C}$. Time to maximum temperature was 60 
minutes for all cooking trials, the time at maximum temperature was 120 minutes kept constant for all trials under study as mentioned in Table 4.

The pulps were subjected to beating in Valley beater according to TAPPI200-sp-01, evaluated at 25 and 40 degree Schopper Reegler ( ${ }^{\circ} \mathrm{SR}$ ) freeness of pulp (Canadian standard method TAPPI 227om-99), Kappa number (TAPPI-236 om-99), physical testing of pulp sheets (TAPPI-220-sp-01). Conditioning of testing atmosphere (TAPPI-402-sp-98), folding endurance (TAPPI423cm-98) Burst strength (TAPPI403om-97), tearing resistance (TAPPI-414 om-98), and Tensile (TAPP-404-cm-92). Hand sheets were prepared using a rapid-Kothen sheet forming machine and tested using TAPPI standards.

\section{Results And Discussion}

Physical properties of $C$. africana wood were shown in Table 1 (Tuphach, 2008). The average basic density was $\left(410 \mathrm{~kg} \mathrm{~m}^{-1}\right)$ and bark-to- wood ratio were in the medium range for tropical hardwoods (Rhydolm, 1965). This will not cause wear on chipper knives in pulp mills with normal liquor-to wood ratio (usually 4:1), impregnation will be easy as yield of pulp per unit volume is related to basic density. The heat value was $18187 \mathrm{~K} \mathrm{j} \mathrm{Kg}^{-1}$ indicating their suitability in coal firewood production and indicated a high lignocellulosic materials could be expected.

The fiber length for $C$. Africana $(1.31 \mathrm{~mm})$ as presented in Table 2 was considered as medium fibred species, therefore it does not need to be mixed with other long fibered wood pulp to obtain good paper properties very good tear resistance could be expected from this raw material. The comparatively wide lumen and fiber diameter indicated that to collapse easily and produce good surface contact between adjacent fibers of $C$. africana, this supported further with morphological indice (Table 2).

The chemical constituents of $C$. africana wood were reflected in Table 3 , the inorganic components (ash and silica) were high (5.84\% and $2.65 \%$ respectively) may cause an increase in alkali consumption and negatively affect the black liquor recovery. The average cellulose content $(48.7 \%)$ was in normal range for tropical hardwoods according to Hale classification (1959) and good pulp yields could be expected from $C$. Africana wood, it is well known that Kurschner- Hoffer cellulose gave less percentage when compared to alpha cellulose thus may results of high yield of this raw material if appropriate cooking conditions used. The lignin content was medium (23.9\%) which indicated normal delignification of wood chips. However $1 \% \mathrm{NaOH}$ soluble (20.2\%) reflected normal cooking parameters should be applied.

The cooking conditions and yield for $C$. africana wood were given in Table 4. At same pulping conditions C. africana chips have shown lower screened yield (41.5 and $44.7 \%)$ when cooked with soda process, whereas the screened yield was increased with addition of $0.13 \%$ AQ to $47.7 \%$ and $53.6 \%$. The bleachable pulps resulted when soda-AQ cooking were used. These results indicated clearly the superiority of soda cooking when anthraquinone applied as catalyst, thus improve yield, and reduce rejects with bleachable Kappa numbers although the initial ISO brightness more or less similar during soda pulping with or without anthraquinone. 
The unbleached pulps evaluation was given in Table 5, indicated that when hand sheets of C. africana tested at both 25 and $40{ }^{\circ} \mathrm{SR}$ gave high tensile index, tear index, burst index and folding endurance, all the mechanical strength properties were increasing with increase of beating degree showed that still fibers were strong enough even at high degrees of beating and pulps of this raw material can be used for wrapping paper and paperboard.

\section{Conclusion}

Based on physical and morphological properties, the wood of Cordia Africana could be considered as medium range pulpwood.. The use of soda-AQ pulping process for $C$. africana wood has accelerated delignification and beating rate, decreased the alkali consumption and increased yield.

The final products of pulping with this raw material is strong enough for wrapping paper and paperboard.

Cordia africana tree is hard wood distributed in both Sudan and South Sudan, it is grown naturally, it is fast growing species, with all promising results of physical properties, chemical composition, fiber morphology and pulping with low cost soda with anthraquione cooking conditions could be one of tree species to establish integrated pulping industry between the two neighboring countries.

\section{Declarations}

\section{Acknowledgments}

The authors would like to express their thanks to National Centre for Research, Khartoum, Sudan for using their facilities and support, with all data and materials are available,

\section{Competing of interest}

The authors declare that they have no competing interests

\section{References}

Ahmed, H.O. Kordofani, M.A. (2012). Morphological and anatomical studies of Cordia abyssinica R.Br. and Cordia sinensis Lam. (Boraginaceae) in Sudan. J. Chem. \& Pharm. Res.4 (10):4582-4588

Andrews F W. (1956). The flowering plant of the Anglo. Egyptian Sudan, vol.3, Buncle \& Co.Itd. Arbroath, Scotland. 579p.

Baye, D. (2016).Socio-Economic Importance of Selected Indigenous and Exotic Tree Species used in Dabat District, North Gonder, Ethiopia. M.Sc. Thesis Addis Ababa University Ethiopia, 53p.

Bolza, E and Keating, W.G. (1972). African Timbers - The Properties, uses and Characteristics of 700 species, Div. of Building Research, 723 p. 
B.S.373. (1957). The British Standard Methods of Testing Small Clear Specimens of Timber. British Standards Institute, London.

EL Amin, H.M. (1990). Trees and Shrubs of Sudan. Ithaca Press, Exeter, 484p.

Elzaki, O.T. (1990). Utilization potentialities of some Exotic Fast Growing wood species grown in Western Sudan. Ph.D. thesis University of Khartoum, Sudan,228p.

Elzaki, O.T. Otuk, S. Khider, T.O. (2012). Sulfur-Free Pulping Of Crateva Adansonii From Sudan. J. of Forest Prod. and Indus. 1(1), 23-26

Emmanuel Neba, N. (2010). Implications Of Fuel Wood Yield, Availability And Harvest In Tubah Mountain Forest, Cameroon. Global J. of Human-Social Science Res., 10 (3): 49-55.

FAO. (2007). Ecocrop Cordia africana. Available at: <http://ecocrop.fao.org/ecocrop/srv/en/cropView? id=4855> (accessed: 2812 2009).

Friis, I. (1992). Forests and Forest Trees of Northeast Tropical Africa - Their Natural Habitats and Distribution Patterns in Ethiopia, Djibouti and Somalia. London: Her Majesty's Stationery Office.

Guyassa, E. Tesfaye, S. Joseph A. Abdulkadir A. Gures, A. (2013). Morphology Characterization of Cordia africana Populations at Six Provenances in Northern Ethiopia. Int. J. Agri. Sci. \& Res. (IJASR), 3(2):175186.

Hale, T.D. (1959). Physical and Anatomical characteristics of Hardwoods. Tappi, 42, (8):670-677.

Horn, R. (1978) .Morphology of Pulp Fiber from Hardwoods and Influence on Paper Strength. Forest Prods. Lab. Report, Madison, 312p.

ICRAF. (2008). Cordia africana. A tree species reference and selection guide World agroforestry center database. Nairobi: ICRAF. Available at:

http://www.worldagroforestry.org/treedb2/AFTPDFS/Cordia_africana.pdf (accessed: 410 2008)

ISO standards 2003. International Organization for Standardization.

Issa, T.; Mohamed, Y.; Yagi, S.; Ahmed, R.; Najeeb, T.; Makhawi, A; Khider, T. (2018). Ethnobotanical investigation on medicinal plants in Algoz area (South Kordofan), Sudan J. Ethnobiol. Ethnomed, 14, 31. 4

Jansen, P. C. M. (1981). Spices, condiments and medicinal plants in Ethiopia, their taxonomy and agricultural significance. Wageningen, Landbouwhogeschool: Centre for Agricultural Publishing and Documentation, Issue 906 of Agricultural Research Reports. 327 pp.

Kent, M., \& Coker, P. (1992). Vegetation Description and Analysis: A Practical Approach (pp. 167-169). New York: John Wiley and Sons. 
Khider,T.O. Elzaki, O.T. (2012). Heat Value of Four Hardwood Species from Sudan. Journal of Forest Prod. \&lndus., 1(2): 5-9

Khristova, P, Gabir, S and Taha, O. (1989). Physical, morphological and chemical characteristics of some exotic fast growing species in Sudan, Cell. Chem. and Tech., 23:121-129.

Obeng, E.A., (2010). Cordia africana Lam. Record from PROTA4U. Lemmens, R.H.M.J.,

Louppe, D. \& Oteng-Amoako, A.A. (Editors). PROTA (Plant Resources of Tropical

Africa/Ressources végétales de l'Afrique tropicale), Wageningen,

Netherland.<http://www.prota4u.org/search.asp>. Accessed 2 September 201628 August

2016.

Obolenskaya, A.V., V.P. Tshegolov, G.I., Akim, N.C., Kossoviz, N. L., Emelyannova, I.Z. (1965). Practitcheshie Raboti po Himii Drevesinii Tzellulozi. Moscow, Lesporm. (In Russian)

Orwa C, A Mutua, Kindt R, Jamnadass R, S Anthony. (2009) Agroforestree Database:a tree reference and selection guide (http://www.worldagroforestry.org/sites/treedbs/treedatabases.asp)

Palgrave, K.C. (2003). Trees of Southern Africa. Revised edition. C. Publishers, Cape Town, South Africa

Raga D. Denu, D. (2017). Population Density of Cordia africana Lam. across Land Use Gradients in Jimma Highlands, Southwest Ethiopia. Population Density. Basic and Applied Research (IJSBAR). 35, (2): 157-166

Rhydolm, S.A. (1965). Pulping Processes. Inter science Publishers, New York. Pp 50-52

Sahni, K. C. (1968). "Important Trees of the Northern Sudan", Khartoum University Press, Sudan U. N. D. P and FAO.

Schmidt, L. H., Mwaura, L. (2010). Cordelia africana Lam. Seed Leaflet, 147p

TAPPI (2002). Standards and Suggested Methods. TAPPI Press, Atlanta, Georgia, USA.

Tamene, W. G. (2017). Germinatio and Early Growt Performances of Cordia africana Lam. in Potted Vertisol and Nitosol in Bichena Town, East Gojjam Zone Amhara Regional State. M.Sc. Thesis, Addis Ababa University, Department of Zoological Sciences, Ethiopia 67p.

Tuphach, S.O. (2008). Suitability of Some Wood Species from Upper Nile State for Pulp and Papermaking. M.Sc. Thesis Faculty of Forestry, University of Khartoum, Sudan 94p.

\section{Tables}


Table 1. Physical properties and heat value of Cordia africana wood

\begin{tabular}{lcl}
\hline Physical properties & Measured value & standard deviation \\
\hline Tree age, years & 6 & 0.48 \\
Basic density, $\mathrm{Kg} \mathrm{m}^{-3}$ & 410 & 0.57 \\
Bark- to wood ratio by volume, \% & 5.44 & 0.32 \\
\hline Bark-to wood ratio by mass, \% & 6.86 & 0.24 \\
\hline Heat value, $\mathrm{Kj} \mathrm{Kg}^{-1}$ & 18187 & 0.27 \\
\hline
\end{tabular}

Table 2. Fiber dimensions and morphological indices of Cordia africana wood

\begin{tabular}{lcc}
\hline Fiber dimensions & Measured value & Standard deviation \\
\hline Fiber length, mm & 1.31 & 0.86 \\
Fiber width, $\mu \mathrm{m}$ & 30.4 & 0.55 \\
\hline Lumen width, $\mu \mathrm{m}$ & 20.2 & 0.43 \\
\hline Wall thickness, $\mu \mathrm{m}$ & 5.1 & 0.57 \\
\hline Morphological indices & & \\
\hline Runkel index & 0.50 & \\
Wall fraction & 33.6 & \\
\hline Flexibility coefficient, \% & 66.4 & \\
\hline Rigidity coefficient, \% & 16.8 & \\
\hline Felting power (slenderness) & 43.1 & \\
\hline
\end{tabular}

Table 3. Chemical Constituents of Cordia africana wood 


\begin{tabular}{lc}
\hline \multicolumn{1}{c}{ Chemical components, \% } & Cordia africana wood \\
\hline Ash & 5.84 \\
Sulfate ash & 2.39 \\
Total silica & 2.65 \\
Solubility in & \\
\multicolumn{1}{c}{ Hot water } & 18.1 \\
Cold water & 0.6 \\
Alcohol & 2.9 \\
1\% NaOH & 2.3 \\
Kurschner- Hoffer cellulose & 20.2 \\
Holocellulose & 48.7 \\
Pentosans & 69.5 \\
Lignin & 25.0 \\
Total extractives & 23.9 \\
Cellulose lignin ratio & 7.3 \\
\hline
\end{tabular}

Table 4. Pulping conditions and yield results of Cordia africana wood 


\begin{tabular}{lcccc}
\hline Pulping Process & Soda & Soda & Soda-AQ & Soda-AQ \\
Cook code & CA1 & CA2 & CA3 & CA4 \\
\hline $\begin{array}{l}\text { Pulping conditions } \\
\text { Active alkali as } \mathrm{Na}_{2} \text { O on oven dry wood, \% }\end{array}$ & 15 & 12 & 12 & 14 \\
Anthraquinone on oven dry wood, \% & 0 & 0 & 0.13 & 0.13 \\
Liquor to wood ratio on oven dry wood, & 4 & 4 & 4 & 4 \\
Maximum temperature, ${ }^{0} \mathrm{C}$ & 170 & 170 & 170 & 170 \\
Time to maximum temperature, min & 60 & 60 & 60 & 60 \\
Time at maximum temperature, min & 120 & 120 & 120 & 120 \\
H-factor & 1620 & 1620 & 1620 & 1620 \\
Yield results & & & & \\
Total yield, \% & 41.8 & 51.8 & 53.9 & 53.7 \\
Screened yield, \% & 41.5 & 44.7 & 47.7 & 53.6 \\
Rejects, \% & 0.3 & 7.1 & 6.2 & 0.1 \\
Kappa number & 27.3 & 29.5 & 26.6 & 21.4 \\
ISO brightness, \% & 21 & 22 & 23 & 22 \\
\hline
\end{tabular}

Table 5. Unbleached pulp evaluation at 25 and $40{ }^{0}$ SR freeness for Cordia africana wood

\begin{tabular}{|c|c|c|c|c|c|c|}
\hline & $\begin{array}{l}\text { Screened } \\
\text { yield, \% }\end{array}$ & $\begin{array}{l}\text { Kappa } \\
\text { number }\end{array}$ & $\begin{array}{l}\text { Tensile } \\
\text { index, } \mathrm{Nmg}^{-} \\
1\end{array}$ & 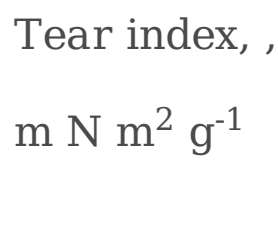 & $\begin{array}{l}\text { Burst index, } \mathrm{K} \\
\mathrm{Pa} \mathrm{m}^{2} \mathrm{~g}^{-1}\end{array}$ & $\begin{array}{l}\text { Folding } \\
\text { endurance, } \\
\text { Log } n\end{array}$ \\
\hline 25 & 53.6 & 21.4 & 34.2 & 8.2 & 2.7 & 1.3 \\
\hline${ }^{0} \mathrm{SR}$ & & & & & & \\
\hline 40 & 53,6 & 21.4 & 34,4 & 8.9 & 3.2 & 1.5 \\
\hline${ }^{0} \mathrm{SR}$ & & & & & & \\
\hline
\end{tabular}

